\title{
Walter Benjamin, la embriaguez urbana y el despertar político de las masas
}

\author{
8 Nahuel Michalski \\ Universidad de Buenos Aires, Argentina
}

Recibido el 03/10/2020. Aceptado el 28/12/2020.

\begin{abstract}
Resumen
En el Librode los Pasajes, Benjamin apela a la dialéctica de las imágenes para analizar el devenir de la experiencia de embriaguez (ensoñación psicofísica) de las masas urbanas en la forma del despertar de su conciencia histórico-política. Esto, según Benjamin, resulta posible gracias a que lasimágenes oníricas que embriagan a las masas son también imágenes dialécticas que arrastran una potente carga histórica contenida en ellas. A continuación, se desarrolla dicha dialéctica partiendo de la categoría benjaminiana mediadora de embriaguez anamnética capaz de activar y vincular los polos del proceso dialéctico a partir del concepto fundamental de rememoración. Finalmente, se ofrecen una serie de conclusiones que pretenden contribuir a iluminar los planteos de Benjamin en torno al vínculo entre experiencia histórica, mesianismo y política.
\end{abstract}

Palabras clave: Benjamin, despertar, imagen, política.

\section{Walter Benjamin, the urban drunkenness and the political awake- ning of the masses}

\begin{abstract}
In the Book of Passages, Benjamin appeals to the dialectic of images to analyze the becoming of the drunken experience (psychophysical reverie) of the urban masses into the form of the awakening of their historical-political consciousness. This, according to Benjamin, is possible thanks to the fact that the dream images that get the masses into drunkenness are also dialectical images that carry out a powerful historical charge contained in them. Next, this dialectic is developed starting from the Benjaminian mediating category of anamnetic drunkenness which is capable of activate and link the poles of the dialectical process from the fundamental concept of remembrance. Finally, a set of conclusions are offered aiming to help illuminate Benjamin's proposals regarding the link between historical experience, messianism and politics.
\end{abstract}




\section{Introducción}

Habiendo tomado distancia de la perspectiva surrealista de la imagen [Bild] que había defendido en su ensayo de $1929^{\circ}$, Benjamin avanza en el Libro de los Pasajes exhibiendo una configuración de la misma caracterizada por su naturaleza dialéctica. De hecho, la noción explícita de imagen dialéctica que responde a ello aparece tanto en el resumen de 1935 como en la totalidad del convoluto N de dicha obra capital. En este marco, hay que tener en cuenta que, tal y como Tiedemann (editor del proyecto de los Pasajes) lo afirma, Benjamin en realidad "procedía por imágenes [...] las imágenes se le hacían dialécticas" (Benjamin, 2005: 28, la cursiva es propia). Es decir, Benjamin exhibe en los Pasajes una naturaleza dialéctica de la imagen que impregna los diversos y múltiples ámbitos de su reflexión tardía: la imagen dialéctica es entender a las imágenes como dialécticas; en dialéctica.

Ahora bien, al analizar los convolutos $\mathrm{M}$ y N de los Pasajes, resulta posible observar la manera en la que Benjamin se vale de dicho potencial dialéctico de las imágenes para vincular la experiencia de ensoñación ideológica y embriaguez psicofísica de las masas parisinas decimonónicas (en adelante, utilizaremos para dicho fenómeno compuesto el término embriaguez), con el despertar de su conciencia histórica y política a partir de la rememoración o anamnesis; experiencia que, por cierto, siempre es una experiencia de equivalente al umbral del despertar (García, 2015; Menninghaus, 2013). Gracias a la rememoración, las imágenes oníricas que mantienen a las masas en la embriaguez devienen en imágenes dialécticas e históricas que cumplen la función de rescatar (actualizar) la historia del olvido de la barbarie con la que se pagó el sueño mítico y fetichista del progreso capitalista. En caso de no haber recuerdo e interpretación de lo recordado a partir de la imagen dialéctica, el pasado continuará expresando su condición sintomática e irresoluta en la embriaguez onírica de los pasajes de París. Por consiguiente, y en los términos psicoanalíticos que proponen Castel (2010) y Naishtat (2016), el despertar histórico y político de las masas consiste en la liberación de las fuerzas del pasado reprimido que laten en el presente (en el que han dejado sus huellas), a través del recuerdo interpretativo: "el despertar es el giro dialéctico, copernicano, de la rememoración” (Benjamin, 2005: 394).

Como se verá, este proceso es articulado dialécticamente por Benjamin a través de dos figuras. Por una parte, el flâneur del convoluto M de los Pasajes capaz, en virtud del reconocimiento de las huellas del pasado inscriptas en la materialidad de urbana (Abadi, 2011, 2013), de activar el proceso de rememoración a partir de la misma experiencia de embriaguez (Opitz \& Wizisla, 2014: 319-339), y que por ello mismo es una embriaguez anamnética (Benjamin, 2005: 422). Por la otra, el historiador del convoluto $\mathrm{N}$ de la mencionada obra es quien tiene a su cargo la tarea de la reconstrucción (montaje) de las imágenes dialécticas y de su interpretación memoriosa a partir de la legibilidad y citabilidad del índice histórico en ellas develado. Por tanto, el flâneur, precisamente en virtud de que es capaz de recordar asume entonces el rol del historiador. En este marco, como se verá, la imagen dialéctica (devenida a partir de la

1 Como se verá en el presente trabajo, la noción de imagen onírica propia de la embriaguez urbana sí forma parte de las influencias surrealistas en el pensamiento benjaminiano y, de hecho, serán aquí capitalizadas en dicha instancia. El desplazamiento que Benjamin realiza con respecto a la perspectiva surrealista de la imagen como ensoñación tiene lugar bajo sus planteos tardíos en torno al momento dialéctico del despertar. Para una excelente explicación acerca de dicho corrimiento, cfr. García (2015). También, conviene la aclaración proporcionada por Tiedemann (editor del proyecto de los Pasajes) en Benjamin (2005: 15-17). 
imagen onírica) cumplirá el rol central de la interrupción del tiempo histórico a partir de la cesura misma del pensamiento permitiendo el comentario final del historiador y su decantación (actualización) en lo que Benjamin denomina verdad monadológica, una forma de verdad que ha sido "arrancada de la historia" (Benjamin: 2005: 477).

A continuación, se desarrolla el proceso introducido enfatizando a modo de hipótesis que la categoría de embriaguez anamnética opera como una idea mediadora fundamental en el análisis de Benjamin. En dicho marco, se procede según dos apartados. El primero de ellos amplía la noción de embriaguez anamnética vinculada a la figura del flâneur a partir del doble efecto producido por las imágenes oníricas de la ciudad: psicofísico e ideológico. Con respecto a esto, se hace hincapié en la idea de recepción en la dispersión (Eiland, 2010) y superposición de tales imágenes y del valor que esto implica para la activación de la rememoración en virtud de ser lo que termina por posibilitar la detección de huellas mnémicas que sugieren la "interpenetración del pasado y el presente" (Eiland, 2010: 69); es decir, la posibilidad (pues el pasado no se encuentra sellado ni es algo "que ha sido") de liberar revolucionariamente las fuerzas contenidas de la historia y disolver su carácter sintomático (irresoluto). Esto último, asimismo, resulta posible en virtud de la capacidad del flâneur para controlar con astucia y cinismo el estado de embriaguez, lo cual impide que sea completamente "absorbido" por este y que, por tanto, tenga lugar la activación del recuerdo.

Por su parte, en el segundo apartado se recogen las conclusiones del primero (la activación del recuerdo a partir de la embriaguez urbana) en pos de exhibir la manera en la que Benjamin se aleja del campo de la ensoñación (inducido por las imágenes oníricas de la ciudad) en dirección de orientarse al despertar-rememorar histórico y político en la imagen dialéctica llevado a cabo por la figura del historiador. En dicha instancia, se aclara el valor fundamental del montaje (Benjamin, 2005: 462) de imágenes dialécticas, pues a partir de allí la legibilidad de su índice histórico habilita la cita (invocación) del pasado, su comentario (interpretación) redentor y la actualización final en la forma monadológica de la verdad. En este marco, de lo que se trata es de aprovechar no solo los elementos de las imágenes oníricas gracias a los cuales devienen dialécticas (histórico-memoriosas), sino también, y principalmente, la chance mesiánica que favorece dicho proceso de interrupción del continuum histórico (lo cual se expresa en el montaje y superposición de imágenes dialécticas) a través de una sincronización divina y oportuna que, como veremos, se da a modo de relámpago.

\section{El flâneur: embriaguez urbana y rememoración}

El Libro de los Pasajes ofrece una amplia y compleja variedad de conceptos en virtud de los cuales Benjamin lleva a cabo sus estudios de la vida social en los pasajes del París decimonónico. Dicha obra, cuyo armazón conceptual se estructura a la manera descentrada de una constelación de ideas, resulta inconclusa y asistemática y, como Tiedemann (editor de los Pasajes) lo afirma, se trata de "un proyecto que ocupó durante trece años a Benjamin, desde 1927 hasta su muerte en 1940, proyecto que con seguridad consideró la culminación de su obra" (Benjamin, 2005: 9)'. Sin embargo, incluso frente a la dificultad implicada por cualquier intento de clausurar sistemáticamente el pensamiento de Benjamin en los Pasajes, ciertamente hay un hilo conductor (entre otros) en el desarrollo del mismo, a saber: el vínculo entre las transformaciones de la vida en la ciudad impulsadas por las pujantes potencias materiales e ideológicas del 
capitalismo $^{3}$ y las consecuencias por esto implicadas en la dimensión experiencial psicofísica de las masas urbanas. Se trata de una dimensión vinculada con la imagen, la memoria y la cognición que Benjamin modula dialécticamente entre lo onírico propio de la embriaguez capitalista, y el umbral (García, 2015: 115) de la vigilia asociado a la lucidez y la toma de conciencia histórico-política: “[...] el nuevo método de la historiografía: el dialéctico. Pasar con la intensidad de los sueños por lo que ha sido para experimentar el presente como el mundo de la vigilia al que se refieren los sueños" (Benjamin, 2005: 835).

Ahora bien, inspirado significativamente tanto por los escritos de Baudelaire ${ }^{4}$ como por el movimiento surrealista, Benjamin alimenta el Libro de los Pasajes con la figura social del flâneur (transeúnte que deambula por la ciudad de París) para dar cuenta del peculiar y paradigmático concepto de embriaguez anamnética en el que resulta posible recoger lo antes dicho. En virtud de la riqueza del mismo y en aras de obtener claridad conceptual, procedamos a definirlo tal y como figura en los Pasajes para luego analizarlo separadamente. Dice Benjamin:

La embriaguez anamnética con la que el flâneur marcha por la ciudad no solo se nutre de lo que a este se le presenta sensiblemente ante los ojos, sino que a menudo se apropia del mero saber, incluso de los datos muertos, como de algo experimentado y vivo (Benjamin, 2005: 422).

Como se puede apreciar, la definición brindada admite una bipartición entre (a) la embriaguez como el efecto de lo que al flâneur "se le presenta sensiblemente ante los ojos", esto es, las imágenes recepcionadas en la ciudad, y (b) el momento anamnético por el cual, a partirde dichas imágenes, el flâneur logra apropiarse de un cierto saber en tanto "experimentado y vivo", es decir, recordado $\sigma^{6}$.

Con respecto a la primera partícula (la embriaguez), esto le ocurre al paseante urbano inquieto y pletórico de tedio (pues no hay realidades significativas en una ciudad cuyo exceso de novedad es en realidad el "eterno retorno mítico de lo mismo") al interior de un París espectral que "se le abre como paisaje [y] le rodea como habitación" (ibíd.: 422). En este contexto, la saturación senso-cognitiva del flâneur es máxima, no solo por la compresión y cercanía del mundo de cosas que "se le presenta sensiblemente ante los ojos", sino también por la intensificación de la estimulación producida por los procesos industriales, la fuerza técnica de los aparatos y el abarrotamiento de espacios, objetos y mercancías. Así, el flâneur pasea ("callejea", nos dice Benjamin) por la ciudad embriagado por la intensa "captación [recepción] de impresiones urbanas" (Scheurmann \& Scheurmann, 1992: 218). De aquí que resulte posible hablar de una

3 Con respecto al énfasis de Benjamin en torno a la fetichización de la vida en la moderna sociedad capitalista, se debe tener en cuenta su lectura de la obra de Lukács (fundamentalmente Historia y conciencia de clase), la cual tiene lugar hacia 1924. Al respecto de ello, cfr. Eagleton (2006: 400-403). También, Adorno, T. (1962). Prismas. La crítica de la cultura y la sociedad (trad. Sacristán, M). Barcelona: Ariel. Asimismo, en un intercambio epistolar de 1935 con su amigo Scholem y registrado en el Libro de los Pasajes, Benjamin comenta que de lo que se trata en dicha obra es del "carácter de fetiche de la mercancía" (2005: 916).

4 Para un acercamiento tanto a la influencia de Les Fleurs du Mal de Baudelaire en los Pasajes de Benjamin, como a las distancias que el pensador alemán marca frente al poeta francés (sobre todo en lo que respecta al carácter romántico de la producción tardía de este último), cfr. Scheurmann, Scheurmann (1992: 220-227). También Opitz \& Wizisla (2014: 45-62).

5 En un intercambio epistolar de 1935, Benjamin le declara a Adorno que Aragon (exponente del surrealismo) había sido una de las principales inspiraciones primerizas del Libro de los Pasajes (Benjamin, 2005: 918-921) pero que en adelante se alejaría de sus ideas. Sin embargo, siguiendo a Heinz Brüggemann (Opitz, Wizisla, 2014: 902-905), vale aclarar que si bien Benjamin no deposita ya en dicho movimiento de vanguardia la esperanza revolucionaria, sí utiliza su armazón de conceptos para describir los efectos de las alteraciones ideológico-perceptivas producidas por la vida en la ciudad. En otros términos, Benjamin no se aleja del surrealismo tanto por los usos que este hace, por caso, de la dimensión onírica y sus vínculos con la urbanidad sino por la ausencia que observa en Dada, Aragon o Breton de una teoría revolucionaria del despertar.

6 Para profundizar en la cercanía establecida entre Benjamin y Platón a partir del concepto de recuerdo o rememoración, se recomienda Fernández Mouján, R. (2019).

7 Resulta de interés el análisis de Benjamin acerca del tedio como sentimiento urbano asociado al eterno retorno mítico de lo mismo (aunque vivido como "novedad"), y el vínculo trazado entre esto, el concepto de fetiche y la crítica al pensamiento de Nietzsche. Cfr. Opitz \& Wizisla (2014: 762-766) y Benjamin (2005: 127). 
experiencia de embriaguez asociada a un estado de recepción en la dispersión (Eiland, 2010: 60) caracterizado, a su vez, por la rapidez y superposición (Opitz, Wizisla, 2014: 897) de imágenes referidas a ese "mundo técnico y sintético de cosas" (ibíd.: 899) que las masas terminan habitando. Se trata de la intensa "variabilidad nubosa de las cosas en el espacio de la visión" (Benjamin, 2005: 849) a la que Simmel, autor que Benjamin estudió cuidadosamente ${ }^{10}$, había definido en su obra La Metrópolis y la Vida Mental citada luego por Martin Jay: "La base psicológica del tipo de individuo metropolitano consiste en la intensificación de la estimulación nerviosa, que resulta del cambio raudo y sin solución de continuidad de estímulos internos y externos" (Jay, 2007: 94). Incluso, y en línea con esto, Buck-Morss indica que la experiencia moderna de la embriaguez urbana "expone el aparato sensorial humano a shocks físicos que tienen su correspondencia en shocks psíquicos" (1993: 70), y que estos, a su vez, implican un modo narcótico de la experiencia (Buck-Morss, 1993: 76; Eiland, 2010: 58) que afecta transitoriamente ${ }^{11}$ la capacidad senso-cognitiva (principalmente memoriosa) del flâneur. De aquí que la embriaguez urbana de los sentidos no deba ser entendida como parálisis, adormecimiento o ralentización, sino (y como Benjamin lo hace al referirse a los efectos del hachís) como intensidad penetrante, éxtasis, y ajetreo; esto es, como un estado sostenido de inquietud en la recepción.

Sin embargo, lo narcótico de la experiencia urbana no se reduce únicamente a lo senso-cognitivo. En términos de contenido ideológico el estado de ensoñación ideológica también forma parte de la embriaguez colectiva. Tal y como se expresa en el resumen de 1935 y en los convolutos K y L de los Pasajes, las imágenes con las que interactúan las masas al vulgarizarse los espacios de la ciudad ${ }^{12}$ son, asimismo, imágenes oníricas (Benjamin, 2005: 45). Dichas imágenes se caracterizan por movilizar en el inconsciente colectivo $^{13}$ la ideología fetichista del progreso tal y como la condensa el capitalismo, esto es, en torno a la percepción del desarrollo lineal, continuo y homogéneo de la historia. A esta invisibilización (que es una forma de olvido) de las reales implicancias de la historia productiva humana (la disrupción, la barbarie y el dolor) se le suma, tal y como advierte Menninghaus (2013), el hecho de que las imágenes oníricas sostienen en el fetiche colectivo la abrumadora potencia naturalizante del mito. Lo mítico (inscripto en las mercancías y actividades de la ciudad parisina) opera ideológicamente como un aplastante eterno retorno del presente que no solo obliga a sellar violentamente el ya violento pasado histórico (a clausurarlo como "ya sucedido" bajo la fuerza de la infinita repetición mítico-natural del ahora), sino que, y precisamente por esto, tampoco habilita la posibilidad de su redención a partir de un cambio cultural y político del estado de cosas (asunto que Benjamin valora precisamente en la acción política de las masas) ${ }^{14}$. Es por esto que para Benjamin, las imágenes onírico-míticas no solo son socias del olvido fetichista del capital, sino que lo son en un sentido particular: el de representar el carácter de lo históricamente reprimido e inconsciente (mientras se

8 "Las calles son la vivienda del colectivo [...] En el pasaje se da a conocer la calle como el interior amueblado de las masas, habitado por ellas" (Benjamin, 2005: 428).

9 Martin Jay ha introducido en el análisis de la relación entre mundo de objetos, imágenes y visión, la idea de un yo oculocéntrico que es capaz, en su mirar, de disolver la contraposición y separación de imágenes en la alucinación y la visión. Esto no sería otra cosa que el relajamiento del yo en la embriaguez en la vivencia de la visión urbana, efecto por el cual el observador queda tomado por un único espacio corporal y gráfico. Cfr. Jay (2007: 117-162).

10 Para más información sobre los vínculos entre Simmel y Benjamin en lo que hace a la vida en la ciudad moderna, cfr. Frisby, D. (1992)

11 Precisamente es el hecho de que el estado de embriaguez aquí descrito resulte transitorio lo que termina por habilitar, según Benjamin el movimiento de restitución dialéctica hacia el umbral del despertar. Si la pérdida de la memoria a partir de la sobreestimulación sensocognitiva de la imagen resultara cabal, no habría entonces posibilidad alguna de rememoración y, consecuentemente, la cadena dialéctica de restitución en el ahora de la cognoscibilidad se vería fracturada, no habiendo entonces toma de conciencia posible. Como se verá más adelante, la transitoriedad del efecto narcótico de la embriaguez que evita que el flâneur quede completamente paralizado en el placer narcótico de la experiencia visual descansa en su capacidad de control (cínico) de lo que acontece.

12 Un interesante desarrollo de esta idea, la cual implica la apertura de los espacios de la ciudad al movimiento desorganizado e inconexo de las masas, puede ser encontrado en Opitz \& Wizisla (2014: 887-955).

13 Para una profundización del vínculo entre Benjamin y el psicoanálisis de Freud, cfr. Castel (2010). También Naishtat (2016).

$14 \mathrm{Al}$ respecto de la relación entre el mito, la imagen y la experiencia capitalista se recomienda con énfasis el abordaje cabal del excelente trabajo de Menninghaus ofrecido en la bibliografía del presente trabajo. Cfr. Menninghaus (2013). 
esté en la ensoñación capitalista). Es en este marco en el que Tiedemann advierte que, en términos ideológicos, las imágenes oníricas expresan "algo irresoluto, irresoluble dentro del capitalismo" (ibíd.: 14) (lo inconsciente reprimido). Es decir, expresan lo irresoluto (violento) del curso histórico que ha quedado mitificado en el eterno presente del consumismo urbano y circunscripto a la idea burguesa del progreso de la historia. De aquí que García afirme que "la imagen onírica, entonces, puede ser pensada [...] como síntoma histórico (2015: 129). Un síntoma que (como todo síntoma) ha plasmado sus huellas en la ciudad de París ${ }^{15}$, las cuales, precisamente por remitir a las heridas del pasado, permiten activar la conjura del síntoma por medio de la rememoración. Pasemos entonces al momento anamnético de la embriaguez en virtud del cual el flâneur comienza a apropiarse de un saber (histórico) en tanto "algo experimentado y vivo"; esto es, en tanto recordado.

Con respecto al momento anamnético, resulta de vital importancia comprender que el mismo proceso de embriaguez senso-cognitivo e ideológico (pues las imágenes de la ciudad son imágenes oníricas) que caracteriza la experiencia visual urbana del flâneur es también el que lo conduce y acerca a su capacidad de comenzar a rememorar (y decimos comenzar pues se trata siempre una experiencia de umbral). Esto se debe a que cuanto más transita por los entornos de la ciudad, cuanto más saturado se encuentra por la superposición contrastante ${ }^{16}$ de imágenes y, por tanto, más involucrado se haya en la experiencia mítica y onírica del capitalismo, tanto más reconoce allí de forma mimético-figurativa (es decir, por la asociación espontánea de afinidades entre imágenes) ${ }^{17}$ la expresión ${ }^{18}$ de las huellas mnémicas ${ }^{19}$ del pasado sintomático inscritas materialmente a su alrededor. De aquí que, en relación al rememorar (con respecto a dicho pasado), Tiedemann haga referencia a la importancia del pathos de la cercanía (Benjamin, 2005: 16) que habilita dicho reconocimiento y que Eiland advierta que "la embriaguez no enturbia [la memoria] sino que la intensifica (2010: 67).

Sin embargo, tal activación del proceso de rememoración del pasado no resulta casual ni se da en virtud de su propia fuerza. El comienzo del pasaje de las ambiguas expresiones oníricas del inconsciente colectivo (marcadas como huellas mnémicas urbanas) a su interpretación en el disparo de la acción memoriosa (comienzo de la toma de conciencia y el despertar), se torna posible en virtud de que el flâneur, a diferencia del mero transeúnte absorbido fatalmente por la experiencia narcótico-ideológica de las imágenes (el "mirón", nos dice Benjamin), resulta capaz de sostener una postura cínica, conscientemente distanciada, con respecto a su propia embriaguez:

notable distinción entre el flâneury el mirón: [...] el simple flâneur... está siempre en plena posesión de su individualidad. La del mirón, por el contrario, desaparece, absorbida por el mundo exterior...que lo golpea hasta la embriaguez y el éxtasis (Benjamin, 2005: 433)

Según Eiland (2010), esta postura es tomada por Benjamin a partir del Campesino de París, de Aragon, el cual gustaba de transitar el culto urbano de lo efímero estando "absorto a sabiendas" (ibíd.: 65, la cursiva es propia). Incluso de forma explícita

\footnotetext{
15 Con respecto a dicho punto particular, se recomienda la lectura de los convolutos $\mathrm{K}$ y L de los Pasajes en los que Benjamin se dedica explícitamente al desarrollo de esta idea. Cfr. Benjamin (2005: 293-421).

16 "No importan los grandes contrastes, sino solo los contrastes dialécticos [...] de ellos se engendra la vida siempre de nuevo" (Benjamin, 2005: 462).

17 Con respecto a la captación de afinidades por medio de la mimesis y lo figurativo, cfr. Buck-Morss (2001: 249, 290-297). También, Abadi (2014: 201-203).

18 Tal y como se percibe, la raíz psicoanalítica del pensamiento benjaminiano obliga a considerar la importancia transversal que se establece entre la expresión inconsciente del síntoma (ensoñación) y su interpretación consciente (despertar). Cfr. Castel (2010).

19 Al modo de la huella mnémica, Benjamin señala que "la huella es la aparición de una cercanía [...] [que] en la huella nos hacemos con la cosa" (Benjamin, 2005: 450). Para profundizar en el concepto benjaminiano de huella mnémica por el cual el pasado se inscribe materialmente en el cuerpo (urbano en nuestro caso) presente, cfr. Abadi $(2001,2013)$.
} 
Benjamin señala que "la figura del detective se halla preformada en la del flâneur" (Benjamin, 2005: 445) al mismo tiempo que nos avisa que la calle lo conduce a "un tiempo desaparecido" (ibíd.: 422). De aquí que la relación dialéctica entre dicho personaje social y la experiencia con la imagen que habilita la rememoración (del tiempo "desaparecido" y sintomático) no sea errática, arbitraria o totalmente inconsciente. El flâneur no solo pasea por la ciudad, sino que precisamente busca huellas, marcas y signos (como el detective, según Benjamin) del pasado. Mira y se mira en el mirar. Se deja llevar por la experiencia, pero con una cierta conciencia. Se acerca a ella, pero a través de una distancia sostenida; es activamente pasivo y, por ello, un cínico. En algún punto, el flâneur sabe lo que hace y, por consiguiente, retiene cierto control, no se encuentra desbocado ni plenamente tomado por lo narcótico del momento de mirar. En otras palabras, el comienzo del despertar en la rememoración a partir de la interpretación de las huellas mnémicas que conduce a la captación de la interpenetración fantasmal entre pasado y presente (Eiland, 2010: 66) solo resulta posible gracias al cinismo astuto y estratégico del flâneur, a que en su mirar hay un cierto control consciente del proceso (Buck-Morss: 1993: 87). Conclusión paradójica: solo porque hay cinismo (en el exclusivo sentido aquí descrito) puede haber entonces una anamnesis en la embriaguez $z^{20}$ que eluda la indeseable posibilidad de que el flâneur quede atrapado en la experiencia ideológica y sensorialmente narcótica con las imágenes de la ciudad.

A partir de lo dicho, de lo que se trata entonces es de saber interpretar dichas imágenes, es decir, de saber leer las marcas y signos ínsitos en ellas en la búsqueda (ya más consciente y despierta) de ese "tiempo desaparecido" referido por Benjamin el cual, por cierto, no se encuentra realmente desaparecido sino reprimido, superpuesto y latente a modo de síntoma en la ensoñación misma del presente de la embriaguez anamnética. Benjamin es contundente: "aprovechar los elementos oníricos al despertar es el canon de la dialéctica" (Benjamin, 2005: 467). Dialéctica que conduce a la comprensión de que las mismas imágenes oníricas que sostienen la embriaguez del sueño capitalista al costo de lo históricamente herido (y aún no sanado), son también aquellas de las que se liberan las fuerzas contenidas de dicha historia irresoluta en la rememoración interpretativa. Este es el proceso dialéctico de comenzar a despertar en las imágenes (que va de lo onírico inconsciente al umbral de la conciencia histórica), y en el que Benjamin deposita las esperanzas de una acción político-revolucionaria que no solo rescate el pasado en el presente (pues el pasado se encuentra superpuesto e inconcluso en este), sino que también rinda homenaje a la barbarie aun no redimida y pulsante (pues todo síntoma siempre retorna) bajo las formas mítico-ideológicas del progreso capitalista. Este es el rol del devenir de las imágenes oníricas en dialécticas. Imágenes estas en las que la verdad del pasado "está cargada de tiempo hasta estallar" (Benjamin, 2005: 465) y reclama ser actualizada en el presente a partir de la labor memoriosa e interpretativa de un flâneur que ahora debe asumir la tarea de convertirse en historiador materialista. De lo que se trata es de "despertar un saber, aun no consciente, de lo que ha sido" (ibíd.: 460) en el "giro dialéctico, copernicano, de la rememoración" (ibíd.: 394).

\section{El historiador: montaje, interpretación y redención histórica}

El apartado previo ha exhibido la naturaleza dialéctica del concepto de embriaguez anamnética por el cual las mismas imágenes ideológicas (oníricas) que embriagan a las masas de la ciudad, habilitan también una dialéctica rememorativa entendida 
como el despertar de la conciencia histórica en torno al carácter sintomático del pasado que late (herido) bajo el presente estado de cosas. En este marco, los elementos in nuce (expresión utilizada en la introducción del presente trabajo) de tales imágenes que permiten dicho movimiento dialéctico serían los siguientes: (a) la superposición de las imágenes ${ }^{21}$ por la cual resulta posible captar miméticofigurativamente la expresión de huellas (mnémicas) del pasado inscriptas en los entornos materiales de la ciudad, (b) la correspondencia de tales huellas con una condición histórica sintomática pasible de ser interpretada, y (c) la actitud cínica (de distancia consciente) y astuta (Benjamin, 2005: 875) que le permite al observador (flâneur) ser amo y esclavo de la propia experiencia de embriaguez (Eiland, 2010: 65): "Se puede determinar la conciencia histórica revolucionaria utilizando [...] la conciencia temporal [...] de quien se encuentra embriagado" (Benjamin, 2005:483, la cursiva es propia).

Ahora bien, en este marco, mientras que en el convoluto $\mathrm{M}$ de los Pasajes dedicado al flâneur (en tanto sujeto paradigmático de las masas), Benjamin discurre en los términos de tales elementos, esto mismo cristaliza en el siguiente convoluto $\mathrm{N}$ bajo el concepto ya definido de imagen dialéctica el cual, además, adopta un tinte explícitamente político, mesiánico y revolucionario. Quisiéramos entonces, sin agotar la riqueza extrema de dicho último convoluto, presentar al menos los ejes conceptuales primarios y vertebrantes de la fundamental noción de imagen dialéctica a partir de la cual Benjamin ya no alude a la figura del flâneur sino a la del historiador-investigador.

Primeramente, vale señalar que en este momento de la dialéctica del despertar (Abadi: 2014: 137), Benjamin es claro acerca de la preeminencia de la actividad racional del proceso la cual toma distancia de la condición próxima al inconsciente onírico en el que primaba el buceo "detectivesco" del flâneur en una sensorialidad urbana narcótica e ideológica. La astucia cínica y embriaga del flâneur ha devenido ahora en el comienzo del despertar de la cognición del historiador. Ya no se trata de la óptica surrealista con la que Benjamin describe la embriaguez anamnética sino de "penetrar con el hacha afilada de la razón [para limpiar] la maleza de la locura y el mito" (Benjamin, 2005: 460). De aquí que Tiedemann indique que "con el motivo del despertar, Benjamin también se supo a la vez separado de los surrealistas" (ibíd.: 16). A partir de aquí, Benjamin ya no enfatiza tanto las imágenes oníricas del inconsciente colectivo cuyas expresiones sintomáticas (huellas, signos) se encontraban marcadas en la materialidad urbana (el cuerpo urbano) ${ }^{22}$, sino más bien el despertar dialéctico a partir de la interpretación del índice histórico latente en ellas ${ }^{23}$. Por esto mismo es que en el resumen de 1935 de los Pasajes, Benjamin había advertido (tal y como se señaló en el apartado previo) que las imágenes oníricas son asimismo imágenes dialécticas, pues el índice de su contenido de verdad (monadológica ${ }^{24}$ ) puede ser interpretado por la cognición del historiador en la dirección de la disolución del síntoma histórico (del pasado no interpretado y pensado por el capitalismo como concluso y "sido");

\footnotetext{
21 No son pocas las alusiones de Benjamin en las que el autor relaciona lo aquí trabajado con modos específicos del mirar. En algún punto, según él, incluso el acto mismo del rememorar (por el cual se recupera dimensión histórica de la experiencia) tiene que ver con "frotarse los ojos", "desplazar el ángulo de la visión" o con sostener "la mirada fija”. En particular, al referirse a la superposición intensa de imágenes (que, como se ha visto, es la base de la embriaguez anamnética del flâneur en la medida que en ella se expresan las huellas del pasado), Benjamin menciona la necesidad de una "visión estereoscópica y dimensional de la profundidad de las sombras históricas". Jay desarrolla este peculiar motivo benjaminiano señalando que la acción binocular caleidoscópica de los ojos permite la captación de contradicciones en la superposición de imágenes, e insinúa la herencia de esta idea en Benjamin a partir de autores como Mallarmé o Marcel Proust (2007: 127-144).

22 Con respecto a esto, Castel señala la cercanía entre el planteo de Benjamin y la noción de histeria (como afección corporal del síntoma reprimido) en el psicoanálisis de Freud. Cfr. (Castel, 2010). Se recomienda también, Weigel (1996: 25-27).

$23 \mathrm{Al}$ respecto, afirma García que "La teoría benjaminiana de la imagen recorre una sinuosa senda puntuada por la vertiginosa alternancia de los nombres de Sorel, Jung y Freud. La interpretación materialista de los sueños se convierte en la mediadora entre la energía depositada en las imágenes colectivas de deseo y la acción política" (2015: 129).

24 Para profundizar en el concepto benjaminiano de verdad monadológica y su vínculo con la detención mesiánico del continuum temporal, se recomienda el comentario de Tiedemann en Benjamin (2005: 28). También, Steiner (2010: 172) y Abadi (2014: 128).
} 
esto es, de la conjura de la ilusión del progreso continuo y lineal de la historia que encubre el hecho verdadero de que "la barbarie se esconde en el concepto mismo de cultura" (ibíd.: 470).

Ahora bien, resulta menester precisar lo siguiente: dicho índice histórico de las imágenes dialécticas consiste en la capacidad de éstas de volverse material de rememoración para una cierta época dada. Se trata de que la rememoración que se había comenzado a "activar" en las expresiones oníricas de la embriaguez urbana del flâneur deviene ahora en una capacidad de citabilidad concreta: "la citabilidad del pasado es la marca de su pertenencia a un tiempo pleno, el índice secreto que lo remite a la redención (Abadi: 2014: 145). Es decir, el índice histórico de las imágenes dialécticas se asocia a una citabilidad en virtud de la cual tales imágenes adquieren, como señala Weigel (1999), una legibilidad [Lesbarkeit] interpretable: "lo real puede leerse como un texto [...] Nosotros abrimos el libro de lo sucedido" (Benjamin, 2005: 466). De aquí que Benjamin advierta que rescatar la historia en el presente en pos de desmitificarla permitiendo la liberación sus fuerzas contenidas y, por tanto, disolviendo el síntoma (la herida, el dolor), sea lo mismo que citar la historia, comentarla, invocarla ${ }^{25}$.

Sin embargo, al respecto de esto, ya se ha señalado en el apartado previo que Benjamin enfatiza la importancia de la percepción ${ }^{26}$ mimético-figurativa ${ }^{27}$ de huellas, signos y rasgos distintivos a partir de la superposición o collage (Jay, 2007: 189; Buck-Morss, 2001: 35) de las imágenes. De hecho, y como se ha señalado, en primera instancia, previamente al momento anamnético, el flâneur se encontraba embriagado por el collage senso-cognitivo e ideológico de imágenes oníricas. Esto último no resulta en absoluto un paso menor del argumento puesto que es precisamente en virtud de dicha superposición de imágenes (y, como se ha señalado, las imágenes oníricas de la ciudad son asimismo imágenes históricas) que la lectura-interpretación mimético-figurativa vinculada al rememorar-despertar no tiene lugar en cualquier momento, ocasión o instancia epocal. Una cierta superposición o collage, a partir de una cierta configuración del montaje de imágenes, tiene que tener lugar para que el historiador realice la interpretación adecuada que conjure lo históricamente reprimido (el síntoma) al permitir su absoluta manifestación (y cristalización como idea monadológica), y para esto resulta menester la colaboración de lo divino ${ }^{28}$. Benjamin indica que es el viento del absoluto lo que provee lo cíclico de la oportunidad ${ }^{29}$ para interpretar, rememorar, y redimir, pero el historiador debe saber (al modo de una exigencia) configurar lo que allí se expresa, debe saber mirar ${ }^{30}$ y montar las velas del concepto (Benjamin, 2005: 475-476) en pos de comprender lo que acontece-acontecido (pues se ha dicho que pasado y presente se superponen e interpenetran). En otras palabras, lo divino ofrece constantemente la chance redentora, pero la humanidad (encarnada en el historiador

25 Acerca de la noción histórico-mesiánica de comentario en Benjamin y su vínculo profundo con la cristalización de la de verdad monadológica, se recomienda con énfasis Opitz \& Wizisla (2014:182-197).

26 Debemos recordar que el pasaje de la mera recepción de imágenes a la percepción de su huella histórica resulta fundamental en el pensamiento dialéctico-revolucionario de Benjamin, pues es el pasaje de la pasividad receptiva a la actividad interpretativa. En lo primero solo hay embriagues senso-cognitiva e ideológica; en lo segundo (tal y como se desarrolló en el primer apartado del presente trabajo) la embriaguez se torna anamnética en virtud de que la percepción penetrante de las huellas mnémicas y signos del pasado permite activar la rememoración en la dirección de la toma de conciencia histórica.

27 Uno de los méritos de la tesis de Abadi consiste en mostrar que el método mimético-figurativo de asociación es el que está presente en las reflexiones de Benjamin tanto al referirse al registro de huellas mnémicas de la imagen onírica, como a la lectura y citabilidad del índice histórico de la imagen: "La facultad mimética es condición de posibilidad de la sincronicidad entre imágenes precisamente porque está vinculada al concepto de lectura. El índice histórico de una imagen depende, según Benjamin, de su legibilidad en un tiempo determinado. En consonancia con esa idea, establece en estos breves ensayos una relación estrecha entre la mímesis y la lectura: la percepción de semejanzas es en última instancia un modo de leer" Cfr. Abadi (2014: 201-202).

28 Esto, por supuesto, atiende a la formación judía de Benjamin gracias a la cual la noción de un Dios redentor de su pueblo (y su historia) era algo absolutamente permanente en su pensamiento. Cfr. Opitz \& Wizisla (2014: 1211-1216).

29 De la misma manera que "como se escribió este trabajo: peldaño a peldaño, según ofrecía el azar un mínimo punto de apoyo al pie" (Benjamin, 2005: 463, la cursiva es propia).

30 "Nunca importan los grandes contrastes, sino solo los contrastes dialécticos, cuyos matices, a menudo para confusión, parecen semejantes" (Benjamin, 2005: 462). 
materialista) debe también saberidentificarla y tomarla en el instante oportuno para la rememoración ${ }^{31}$. De aquí que Benjamin advierta que:

la excepcional volatilidad del objeto histórico (llama), confrontada con la fijación del filológico. Donde el texto mismo es el objetivo histórico absoluto -como en la teología-, él [el historiador] capta en el carácter de la revelación el momento de la máxima volatilidad (ibíd.:1021, la cursiva es propia).

Cuando este acontecimiento de rasgo mesiánico ocurre lo que se obtiene es la superposición justa y el montaje adecuado que habilitan en su sincronización mesiánica la lectura, citación (invocación) y comentario del historiador que conducen a la liberación de lo reprimido en la acción del despertar histórico y político. Se conjura lo mítico ${ }^{32}-$ reprimido detrás de la ensoñación del progreso capitalista y se disuelve entonces el síntoma. Las formas históricas y sus contenidos se unifican en el estallido de verdades monadológicas ${ }^{33}$ a las que se las hace "saltar del [aparente] continuo del curso de la historia [...] en la figura de la controversia histórica [...] [este es] el momento destructivo y crítico de la historiografía materialista [...] cuando hace estallar la continuidad histórica" (Benjamin, 2005: 477). A partir de aquí resulta posible percibir que "lo prehistórico [del presente] ya no queda encubierto" (Benjamin, 2005: 464) por el uso que el capitalismo hizo de él ${ }^{34}$. Por esto mismo, advierte Benjamin, es que a partir del montaje y reconstrucción ${ }^{35}$ por parte del historiador y del compromiso de su mirada caleidoscópica ${ }^{36}$ sobre las imágenes dialécticas discretas y superpuestas ${ }^{37}$ (su saber ver desde múltiples perspectivas), resulta posible configurar una percepción por la cual el presente y el pasado son reconocidos como instancias interpenetradas de un mismo fondo histórico (ibíd.: 461). Esto implica que se dejan de captar como instancias linealmente concatenadas en una continuidad temporal, lo cual, como se dijo, no es sino la base ideológica a partir de la cual el capitalismo ha fundado el fetiche mítico del progreso. De este modo, en este punto crucial de sincronización en la superposición de imágenes dialécticas es cuando "el presente, como lo soñara alguna vez el pasado, se despierta del pasado que él mismo sueña" (Eiland, 2010; 69, la cursiva es propia). El pasado relampaguea desde su discontinuidad inconclusa y es traído sobre y por el presente como la colisión de una sincronía repentina que tiene lugar, como se dijo, gracias a la oportunisima legibilidad y citabilidad del índice histórico de las imágenes dialécticas favorecida por lo divino y aprovechado por el montaje, lectura e interpretación memoriosa del historiador. Por este motivo, es que Tiedemann afirma que "todo presente debería ser sincrónico con determinados momentos de la historia, igual que todo pasado particular solo deviene legible en una determinada época" (Benjamin, 2005: 16, la cursiva es propia): aquella en la que se da la unidad entre la

31 Para una profundización de los elementos teológicos en Benjamin, cfr. Naishtat (2016). También, Opitz \& Wizisla (2014: 1173-1249). $32 \mathrm{Al}$ respecto del concepto de presente mítico en el sentido aquí expuesto, cfr. Naishtat (2016). También se recomienda Buck-Morss (2001: 95-181). Otro excelente desarrollo sobre la relación entre mito, historia y dialéctica (corazón del pensamiento tardío de Benjamin) se puede hallar en Opitz \& Wizisla (2014: 527-591).

$33 \mathrm{Al}$ respecto de la intersección benjaminiana entre marxismo y teología a partir de la doctrina de la reconciliación de forma y contenido histórico (lugar común del marxismo al que recurre el Benjamin tardío), se recomienda el excelente aporte de Terry Eagleton. Cfr. Eagleton, T (2006). La estética como ideología (trad. Cano, G \& Cano, J). Madrid: Editorial Trotta, pp.393-419.

34 Para profundizar en la relación entre lo arcaico, el mito capitalista y la imagen dialéctica como conjura de ello, cfr. Buck-Morss (2001: 130-137).

35 Precisamente en esto reside el carácter barroco de la estética revolucionaria benjaminiana: en que procede a partir de la ruina históricamente misma a la que apuntan los signos y marcas del índice de las imágenes dialécticas. Cfr. Opitz \& Wizisla (2014: 197-241). 36 Cfr. Jay (2007: 140-142).

37 Precisamente esto es lo que habilita la idea de Benjamin del montaje de imágenes de objetos materiales que constituye el método de la historiografía material. El trabajo del historiador materialista consiste en "el arte de citar sin comillas [...] Su teoría está íntimamente relacionada con la del montaje" (Benjamin, 2005: 460) de elementos discretos. Al respecto de esto, Buck-Morss señala que "El principio de construcción es el montaje, donde los elementos ideacionales de la imagen permanecen irreconciliables, en lugar de fusionarse en una perspectiva armonizadora. Para Benjamin, la técnica del montaje posee derechos especiales, incluso totales, como una forma progresista porque interrumpe el contexto en el que se inserta, y de ese modo actúa contra la ilusión" (2001: 84) de la continuidad y el progreso. En otros términos, el montaje permite la interrupción, la no-fusión e identificación de sentido a la que tiende la absorción de la discontinuidad bajo el símbolo totalizante. De manera concomitante, Eiland muestra el vínculo de la teoría del montaje utilizada por Benjamin con el pensamiento optimista de Kracauer que veía en el montaje la posibilidad de emancipar la mirada del público (Eiland, 2010: 60-61). 
voluntad redentora de lo divino y la asunción humana de la tarea histórica, política y material de aprovechar dicha voluntad. De este modo, es en dicha instancia crucial de arriesgada y oportuna concentración de los campos de fuerza dialécticos (de máxima superposición y montaje de imágenes dialécticas) en la que resulta posible para el historiador revolucionario rescatar el pasado para el presente (actualizarlo) y comentar lo sucedido a partir del "choque frontal contra el pasado mediante el presente" (ibíd.: 473); choque que es un súbito rememorar en el ahora de la cognoscibilidad. En virtud de la infinita riqueza conceptual y belleza estilística del fragmento, y de su potencia tanto para sintetizar lo hasta aquí desarrollado como para habilitar el cierre del presente apartado, se cita a continuación el fragmento $\left[\mathrm{N}_{3}, 1\right]$ del convoluto $\mathrm{N}$ de los Pasajes:

[...] El índice histórico de las imágenes no solo dice a qué tiempo pertenecen, dice sobre todo que solo en un tiempo determinado alcanzan legibilidad. $Y$ ciertamente, este <alcanzar legibilidad > constituye un punto crítico determinado del movimiento de su interior. Todo presente está determinado por aquellas imágenes que le son sincrónicas: todo ahora es el ahora de una determinada cognoscibilidad. En él, la verdad está cargada de tiempo hasta estallar [...] No es que lo pasado arroje luz sobre el presente, o lo presente sobre el pasado, sino que imagen es aquello en donde lo que ha sido se une como un relámpago al ahora de una constelación. En otras palabras: imagen es la dialéctica en reposo. Pues mientras la relación del presente con el pasado es puramente temporal, la de lo que ha sido con el ahora es dialéctica: de naturaleza figurativa, no temporal. Solo las imágenes dialécticas son imágenes auténticamente históricas, esto es, no arcaicas. La imagen leída, o sea, la imagen en el ahora de la cognoscibilidad, lleva en el más alto grado la marca del momento crítico y peligroso que subyace a toda lectura. (Benjamin, 2005: 465)

Es posible entender entonces el motivo por el cual Benjamin ve en las imágenes dialécticas no solo la embriaguez de la experiencia capitalista (pues también fueron imágenes oníricas) sino también un potencial histórico-redentor traducido en una latencia mesiánica "en reposo" cargada de verdad histórica y política hasta estallar. Verdad que, para esto último, exige ser leída, citada y comentada en el rememorar para que en su relampagueo haga saltar los goznes de la historia. De este modo, se orienta la interpretación-rememoración en la dirección de liberar las inmensas fuerzas históricas "que permanecen encadenadas en el 'érase una vez' de la historiografía clásica [...] [y que] fue el más potente narcótico del siglo" (ibíd. 465); narcótico ideológico (el de la historiográfica clásica) que, como se ha visto en el apartado previo, fluía en la veloz e inconexa superposición de imágenes que embriagaba al flâneur, pero que ahora ha pegado un "vuelco dialéctico", un auténtico "giro copernicano".

De hecho, es en este justo sentido en el que Benjamin comprende el componente fetichista de la experiencia mercantil que abarrota y satura la experiencia urbana: en el de que la mercancía presenta la historia a la forma idealista y romántica (prosaica y heroica), es decir, como el galope del héroe mítico-burgués a través del frenético progreso histórico lineal y continuo del que la novedad de la mercancía es su expresión más acabada y que se manifiesta como el frenesí (embriaguez) senso-cognitivo urbano en el París decimonónico. De aquí que la función revolucionaria de la imagen dialéctica sea precisamente la inversa, es decir, la de generar la cesura de pensamiento (Abadi, 2014: 184) necesaria que habilita la imposibilidad de identificación simbólica (de cierre) entre pasado y presente (Menninghaus, 2013: 74-76) ${ }^{38}$, y que por tanto activa el 
shock de la interrupción en dirección de captar lo históricamente inconcluso, latente y superpuesto del pasado, y en particular el pasado de los oprimidos, de los que han sufrido, de los que han pagado con su humanidad el costo del mito del progreso.

Al pensar pertenece tanto el movimiento como la detención de los pensamientos. Allí donde el pensar, en una constelación saturada de tensiones, llega a detenerse, aparece la imagen dialéctica. Es la cesura [Zäsur] en el movimiento del pensar. Su lugar no es, por supuesto, un lugar cualquiera. Hay que buscarlo, por decirlo brevemente, allí donde la tensión entre las oposiciones dialécticas es máxima. Por consiguiente, el objeto mismo construido en la exposición materialista de la historia es la imagen dialéctica. Es idéntico al objeto histórico; justifica que se le haga saltar del continuo del curso de la historia. (García, 2015: 130)

De lo que se trata entonces es de interrumpir y detener en la cesura y el rememorar del pensamiento a partir de la imagen dialéctica la percepción que se tiene de la historia como algo suave, continuo y concatenado. $Y$ esto en pos de comprender que el pasado no se encuentra ni concluido ni sellado, y que entonces, justamente por ello, puede ser redimido y ajusticiado:

La historia no es solo una ciencia, sino no menos una forma de rememoración. Lo que la ciencia ha 'establecido', puede modificarlo la rememoración. La rememoración puede hacer de lo inconcluso (la dicha) algo concluso, y de lo concluso (el dolor) algo inconcluso. Esto es teología; pero en la rememoración hallamos una experiencia que nos impide comprender la historia de un modo fundamentalmente ateológico. (Benjamin, 2005: 473)

En el sentido de lo dicho sentido, y al igual que todo síntoma que se expresa en sueños y debe ser interpretado dialécticamente en un despertar de la conciencia, el detonador del proceso redentor en la imagen dialéctica se haya "a la espera" de la sincronía divina en la que el historiador pueda llevar a cabo la interpretación, lectura y rememoración consciente. Es por esto por lo que Benjamin llega a identificar la acción política alentada por la imagen dialéctica con el conocimiento histórico en el marco del recuerdo. Si la acción revolucionaria no consiste per se en un rememorar colectivo que parte del estado de cosas; si no extrae su fuerza dialéctica del pasado inconcluso y potencial que acarrea la promesa realizada a los esclavizados e históricamente incumplida; si el acto de rememorar a partir de la codificación del sutil mapa de signos presente en las imágenes de la ciudad ${ }^{39}$ no contempla lo que podría haber sido y no fue (la justicia humana), entonces la acción política no se reconocerá como mesiánica, ni como conocimiento histórico por parte de las masas ideologizadas; esto es, como redentora. La revolución tiene, por tanto, que ser radical (como las verdades monadológicas), $\mathrm{y}$, por consiguiente, quedar referida a un valor absoluto que se halla en la dimensión teológica de la redención:

Sin teología, sin relación con lo absoluto, la conciencia del ser humano revolucionario comienza a perderse en puros relativismos, pierde la capacidad de comprender lo específico del tiempo histórico; en consecuencia, comienza a trabajar con un concepto homogéneo de tiempo (Scheurmann, 1992: 230-236)

Así, la fuerza liberada por la desmitificación de la imagen debe ser recapturada y redirigida para la acción política consciente; esto es, debe poder liberar un recuerdo por el 
que un pasado se vuelva sincrónico con el presente. De aquí que la imagen dialéctica no sea sino el espaciamiento de la temporalidad histórico-mesiánica como discontinuidad y apertura ${ }^{40}$, como una posibilidad de chance revolucionaria indisociable del despertar en el verdadero conocimiento. En este sentido se abre el espacio histórico-político del recuerdo benjaminiano. Y si la imagen es este espaciamiento redentor de la temporalidad que surge a partir de las imágenes sintomáticas de la vida urbana, del mismísimo embotamiento senso-cognitivo e ideológico que en ella se facilita, entonces la misma imagen que hundía a las masas en la embriaguez de la ciudad ahora se exhibe a sí misma como apertura dialéctica al despertar en la acción política. En última instancia, Benjamin disculpa la embriaguez narcótica del mirón; pero al flâneur que ha alcanzado la anamnesis en ella le exige la tarea de convertirse en el historiador que observe lo inconcluso del pasado para rendirle homenaje, pues, en última instancia:

Solo concebimos la felicidad en el aire que una vez respiramos entre las personas que vivieron con nosotros. En otras palabras, al concebir la felicidad [...] se agita también la idea de la redención [...] la concepción correcta del tiempo histórico descansa por completo y en absoluto sobre la imagen de la redención (Benjamin, 2005: 481)

\section{Conclusiones}

A modo de conclusión, vale indicar que la comprensión de la actualidad epocal resulta impensable por fuera de la dimensión de la imagen, pues ésta se ha convertido en el basamento mismo de la experiencia cultural colectiva. El universo mismo, nos dice Benjamin citando a Baudelaire (Benjamin, 2005: 256) es un almacén de imágenes. Así, no hay nada por fuera de la imagen: la experiencia humana se condensa allí, y sobre todo la del dolor y la injusticia. Comprender la historia en su relación problemática e irresoluta con la expansión moderna de las fuerzas culturales es comprenderla a partir de la reconstrucción y superposición de lo que de ella se moviliza en sus imágenes. De aquí que Tiedemann haya advertido que Benjamin piensa y procede a través de imágenes (Benjamin, 2005, 28).

Pero este pensar y proceder en el que Benjamin confiaba encontrar las fuerzas necesarias para la activación de la conciencia política de las masas, se le da mientras habita las embriagadoras calles del París decimonónico, de cuya intensidad urbana ha extraído gran parte de la inspiración para la escritura de los enigmáticos fragmentos que conforman el Libro de los Pasajes. En esa ciudad onírica (ibíd.: 393), que con sus shocks sensoriales facilita también la ensoñación ideológica, Benjamin fue tanto el flâneur que paseaba embriagado en la recepción dispersa de imágenes oníricas de la modernidad, como el historiador perspicaz y lucido que, buceando precisamente en el éxtasis de dicha experiencia, encontraba la inscripción material de las marcas de un pasado inconcluso que, en su dolor latente, exigía (y quizás continúa exigiendo) ser recordado y redimido. Y es que Benjamin no era un simple mirón, un consumidor más de los narcóticos fetichistas de la ciudad. Él no estaba hundido en el sueño ideológico de que aquello que observaba a su alrededor era el presente deducido de una línea temporal que se dirigía continuamente hacia el progreso. Además, tal y como lo señala en el convoluto D de los Pasajes, había comprendido la manera en la que las fuerzas míticas de la historia resultaban socias de dicha ilusión moderna (la del progreso inevitable) al sellar toda posibilidad de transformación del estado de cosas a través del eterno retorno de lo mismo plasmado en las mercancías a la venta y los 
espectáculos callejeros. En otras palabras, Benjamin era un flanêur astuto y estratega; casi cínico, distanciado de su propia embriaguez, y por ello podía, precisamente, ser historiador; reconstruir y resignificar la historia. Sabía cómo navegar por el deleite psicofísico de la ciudad sin perder por ello su conciencia de investigador de detalles en virtud de los cuales, y gracias a las nociones del psicoanálisis, el arte, la arquitectura, la teología y el materialismo histórico (entre otros campos), comenzar a interpretar los signos aun vivos del pasado irresoluto, colaborando así a disolver su síntoma y liberar sus potencias contenidas, a rescatarlo de su interpenetración con el presente cuyo dolor se expresada en los objetos, espacios, estructuras y contornos de París. Quizás por esto haya señalado en los Pasajes que la tarea del historiador consiste en "descubrir en el análisis del pequeño momento singular, el cristal del acontecer total" (ibíd.: 463). En otras palabras, Benjamin supo cómo hacer de las imágenes oníricas que embriagaban la experiencia de sus coetáneos urbanos, auténticas imágenes dialécticas que se hicieran cargo, al interrumpir el continuum histórico y propender a la cesura del pensamiento en el shock de sentido final, del hecho innegable de que "la barbarie se esconde en el concepto mismo de cultura" (ibíd.: 470).

Sin embargo, para que ello sea posible, para que el despertar de la conciencia histórica y política tenga lugar, el Benjamin historiador señalaba la necesidad de la tarea de recomponer y observar las imágenes dialécticas en dirección de leer en ellas los índices que le permitiesen citar y comentar la historia críticamente, invocarla para arrancarle entonces una verdad (la del dolor no redimido de los oprimidos) que cristalice a la manera de la monada (ibíd..: 477); pues solo "la imagen leída, o sea, la imagen en el ahora de la cognoscibilidad, lleva en el más alto grado la marca del momento crítico y peligroso que subyace a toda lectura (ibíd.: 465). Esto, no obstante, y como se ha visto en el desarrollo del trabajo, no depende de la pura voluntad humana. El éxito de la tarea de reconstrucción histórica con la cual se traerá súbitamente el pasado sobre el presente, invocándolo y reviviéndolo para liberarlo del peso sepulcral de los pasajes de París, depende de que el historiador aproveche la adecuada y justa sincronía de imágenes dialécticas en virtud de la cual todo el pasado pueda presentificarse (mostrarse completamente como presente) con todo su "ha sido" como un "siendo": la oportunidad es tan pequeña y a la vez significativa que entonces tiene que ser de carácter divino. A dicho momento oportuno, totalmente restitutivo y redentor en el que el síntoma del dolor humano se disuelve en el rememorar cabal, Benjamin lo denominó apocatástasis de la historia (ibíd.: 462): "los muertos se levantan".

Desde aquí se capta entonces, tal y como lo hemos hecho en las hojas previas, el componente mesiánico inserto en las reflexiones benjaminianas en torno a la experiencia moderna con la imagen, la historia y la política, puesto que de lo que se trata es de que el historiador sepa captar la chance redentora en la que el Mesías se pone del lado de los históricamente oprimidos. De aquí que, a esta serie de conclusiones finales sea capaz de adicionarse una última: el estudio benjaminiano de la experiencia urbana de las masas decimonónicas y su potencial revolucionario no solo conduce a entender que toda imagen onírica que embriague a las masas modernas ya lleva en sí la fuerza histórica y políticamente transformadora de la imagen dialéctica, sino también que esto resulta posible cuando lo divino acompaña dicho proceso transformador. De aquí que podamos comprender una de las citas más potentes del texto de los Pasajes que se ha visitado en este trabajo; aquella por la cual Benjamin sentencia que: "el auténtico concepto de historia universal es mesiánico. Tal y como se entiende hoy, la historia universal es cosa de oscurantistas" (ibíd.: 488). ${ }^{47}$ 


\section{Bibliografía}

"Abadi, F. (2011). La mímesis como lógica del recuerdo: Una lectura sobre la noción de «imagen dialéctica» en la obra de Walter Benjamin desde una perspectiva warburguiana. En: Contrastes. Revista Internacional de Filosofía, 16, 7-25.

»Abadi, F. (2013). Mimesis y rememoración en Watter Benjamin. En: Aporía. Revista Internacional de Investigaciones Filosóficas, 6, 4-16.

»Abadi, F. (2014). Conocimiento y redención en la filosofía de Walter Benjamin. Buenos Aires: Miño y Dávila.

» Benjamin, W. (2005). Libro de los Pasajes (trad. Fernández Castañeda, L \& Guerrero, Fernando). Madrid: Akal.

" Buck-Morss, S. (1993). Estética y anestésica: Una revisión del ensayo de Walter Benjamin sobre la obra de arte. En: La balsa de la Medusa, 25, 55-98.

» Buck-Morss, S. (2001). Dialéctica de la mirada (trad. Rabotnikof, N). Madrid: Antonio Machado Libros.

"Castel, M. (2010). Temporalidad inconsciente y tiempo histórico: Acerca de la recepción benjaminiana de la obra de Sigmund Freud. En: Acha, O. \& Vallejo, M. (Comps.). Inconsciente e historia después de Freud: Cruces entre filosofía, psicoanálisis e historiografía (pp. 53-69). Buenos Aires: Prometeo.

» Eiland, H. (2010). Recepción en la distracción (trad. Villegas, S). En: Uslenghi, A. (comp.) (2010). Walter Benjamin: Cultura de las imágenes. Buenos Aires: Eterna Cadencia, pp. 53-75.

" Fernández Mouján, R. (2019). "Introducción al platonismo de Walter Benjamin". En: Ideas. Revista de Filosofía Moderna y Contemporánea. №, pp.58-75.

»Frisby, D. (1992). Fragmentos de la modernidad. Teorías de la modernidad en la obra de Simmel, Kracauer y Benjamin (trad. de C. Manzano, Boadilla del Monte). Madrid: Visor Distribuciones.

» García, L. (2015). Una política de las imágenes. Walter Benjamin: Organizador del pesimismo. En: Escritura e Imagen, 11, 111-113.

" Jay, M. (2007). Ojos abatidos. La denigración de la visión en el pensamiento francés del siglo XX (trad. Lopez Martín, F). Madrid: Akal.

"Löwy, M. (1997). Redención y Utopía: El judaísmo libertario en Europa Central. Un estudio de afinidad electiva (trad. Tarcus, H). Buenos Aires: Ediciones El Cielo por Asalto.

"Löwy, M. (2001). Walter Benjamin. Aviso de incendio (trad. Pons, H). Buenos Aires: Fondo de Cultura Económica.

"Menninghaus, W. (2013). Saber de los umbrales. Walter Benjamin y el pasaje del mito (trad. Vargas, M \& Simesen de Bielke, M). Buenos Aires: Editorial Biblos.

" Mosès, S. (1997). El ángel de la historia. Rosenzweig, Benjamin, Scholem (trad. Martorell, A). Madrid: Cátedra.

"Naishtat, F. (2016). Walter Benjamin y la memoria psicoanalítica. En: Una memoria sin testamento. Santiago de Chile: LOM Ediciones.

"Naishtat, F. (2016). Walter Benjamin y sus usos profanos de la teología. En: Revista 
Pilquen, Sección Ciencias Sociales, Universidad Nacional del Comahue, 19, 2, 67-74

"Opitz, M. \& Wizisla, E. (Eds.). (2014). Conceptos de Walter Benjamin (trad. Belforte, M. \& Vedda, M.). Buenos Aires: Las Cuarenta.

"Scheurmann, I. y Scheurmann, K. (Eds.) (1992). Para Walter Benjamin. Documentos, ensayos y un proyecto. Bonn: Inter Nationes.

"Steiner, U. (2010). Walter Benjamin. An introduction to his work and thought (trad. Winkler, M). Chicago: The University of Chicago Press.

»Weigel, S. (1996). Body-and imagen-space. London: Routledge. 